\title{
REAKSI HARGA SAHAM SAAT PENGUMUMAN DIVIDEN TUNAI DIMODERASI OLEH FREE CASH FLOW
}

\author{
Ni Wayan Lady Andini ${ }^{1}$ \\ I.D.G Dharma Suputra ${ }^{2}$ \\ Made Gede Wirakusuma ${ }^{3}$ \\ 1,2,3 Fakultas Ekonomi dan Bisnis Universitas Udayana, Bali, Indonesia \\ Email: ladyandini92@gmail.com
}

\begin{abstract}
ABSTRAK
Penelitian ini menguji reaksi harga saham saat terjadinya pengumuman dividen tunai, yang dimoderasi oleh free cash flow. Informasi tentang pembagian dividen dipercaya dapat memengaruhi perilaku harga saham di pasar modal. Beberapa hasil penelitian sebelumnya masih terdapat inkonsistensi, sehingga variabel free cash flow dimasukkkan sebagai variabel moderasi yang diprediksi mampu memperkuat pengaruh pengumuman dividen tunai pada reaksi harga saham.

Populasi penelitian ini adalah seluruh perusahaan yang terdaftar di BEI periode 2013-2015. Sampel penelitian ditentukan dengan metode purposive sampling, yang menghasilkan 32 sampel tahun 2013, 34 sampel tahun 2014, dan 25 sampel tahun 2015. Teknik analisis data yang digunakan adalah Moderated Regression Analysis (MRA). Hasil penelitian ini menunjukkan bahwa pengumuman dividen tunai berpengaruh positif pada reaksi harga saham, sedangkan free cash flow tidak terbukti sebagai pemoderasi pengaruh pengumuman dividen tunai pada reaksi harga saham. Pengembangan penelitian ini dapat dilakukan dengan mengganti event date menggunakan periode terjadinya RUPS, serta menggunakan kebijakan dividen (meningkat atau menurun) sebagai variabel independen, sehingga mampu membuktikan peran free cash flow sebagai pemoderasi.
\end{abstract}

Kata kunci: pengumuman dividen tunai, free cash flow, harga saham

\begin{abstract}
This study examines the stock price reaction when companies announce cash dividend distribution, which is moderated by free cash flow. Dividend distribution information is believed to affect the stock price. The results of several previous research have inconsistencies. Therefore, the free cash flow variable is included as a moderating variable which is predicted to strengthen the effect of cash dividend announcement on stock price reaction. The population of this research is all companies listed on the BEI in 2013-2015. The sample was determined by purposive sampling method, and produced 32 samples in 2013, 34 samples in 2014, and 25 samples in 2015. The data analysis technique used was Moderated Regression Analysis (MRA). The results of this research indicate that the announcement of cash dividend positively affects the stock price reaction, while free cash flow is not proven as a moderator of the effect of cash dividend announcement on stock price reaction. The future research can be done by replacing the event date using the period of the Annual General Meeting (AGM), and using the dividend policy (increased or decreased) as an independent variable to prove the role of free cash flow as a moderator.
\end{abstract}

Keywords: cash dividend announcement, free cash flow, stock prices 
Ni Wy. Lady Andini, Md. Gd. Wirakusuma, dan I D.G. Dharma Suputra. Reaksi Harga......

\section{PENDAHULUAN}

Reaksi pasar terhadap suatu informasi merupakan hal yang penting untuk pelaku bisnis di pasar modal. Apabila pasar bereaksi secara cepat dan akurat untuk mencapai harga keseimbangan baru, dicerminkan dari informasi yang tersedia, maka kondisi pasar seperti ini disebut pasar efisien. Kunci utama untuk mengukur pasar efisien adalah dengan memperhatikan korelasi antara harga sekuritas dengan informasi yang tersedia (Hartono, 2014:586). Seorang investor yang rasional tentu harus melakukan banyak pertimbangan serta analisa melalui informasi-informasi yang tersedia sebelum membuat keputusan investasi dalam pasar modal. Informasi merupakan suatu kebutuhan bagi para investor dalam pasar modal. Investor harus menerima informasi yang benar, sistem perdagangan di pasar modal dapat dipercaya, serta tidak ada pihak yang memanipulasi perdagangan tersebut.

Salah satu bentuk informasi dalam pasar modal adalah informasi mengenai pengumuman pembagian dividen. Dividen merupakan pendistribusian laba kepada pemegang saham berdasarkan jumlah saham yang dimiliki. Pada umumnya, pembagian dividen dilakukan dalam bentuk kas atau tunai. Pembagian dividen menyebabkan pengurangan jumlah kas yang tersedia bagi perusahaan dan laba ditahan. Lintner (1962), Gordon (1959), dan Bhattacharya (1979), menjelaskan bahwa dividen yang dibagikan seperti bird in the hand yang risikonya lebih kecil dibandingkan dividen yang tidak dibagikan. Hal ini menyebabkan investor cenderung menyukai dividen dengan jumlah yang tinggi. Pembagian dividen akan membuat investor merasa lebih aman, dibandingkan dengan diinvestasikan kembali dalam perusahaan. Apabila dividen dibagikan, investor dapat menerima hasil yang 
nyata, sedangkan apabila laba ditahan untuk reinvesment, akan menimbulkan sesuatu yang belum pasti karena sangat bergantung pada kinerja perusahaan di masa depan. Nugroho (2014) menyatakan bahwa pengumuman dividen digunakan oleh investor sebagai informasi untuk menilai harga saham suatu perusahaan. Jika suatu perusahaan mampu menghasilkan laba yang tinggi, kemudian menyisihkan sebagian dari laba tersebut sebagai dividen dengan jumlah yang tinggi, maka investor akan tertarik untuk membeli saham perusahaan tersebut. Hal ini menyebabkan permintaan atas saham perusahaan emiten tersebut akan meningkat dan harga sahamnya pun akan semakin tinggi.

Perubahan harga dari suatu sekuritas, menunjukkan terjadinya reaksi pasar. Hal ini sesuai penelitian Al-Yahyaee et al. (2011) yang menemukan bahwa pengumuman kenaikan (penurunan) dividen terkait dengan kenaikan (penurunan) harga saham. Reaksi terjadi ketika suatu pengumuman (good news atau bad news) memengaruhi harga (kenaikan atau penurunan) yang melebihi nilai yang aktual atau wajar (abnormal return). Pengumuman dividen dinyatakan memiliki kandungan informasi jika memberikan abnormal return yang signifikan pada pasar. Penelitian yang dilakukan oleh Gordon $(1959,1962)$, Foster dan Vickery (1978), serta Lee (1995) menemukan bahwa terdapat abnormal return positif terhadap pengumuman pembayaran dividen. Bertentangan dengan penelitian tersebut, Easton dan Sinclair (1989) menemukan abnormal return negatif, yaitu reaksi negatif harga saham terhadap pengumuman dividen. Amah dan Nuraina (2012) juga melakukan penelitian mengenai reaksi pasar sebagai dampak pengumuman dividen dengan studi empiris pada perusahaan manufaktur yang terdaftar di Bursa Efek Indonesia 
Ni Wy. Lady Andini, Md. Gd. Wirakusuma, dan I D.G. Dharma Suputra. Reaksi Harga......

(BEI) periode 2004-2006. Hasil penelitian membuktikan bahwa pengumuman dividen tidak memiliki information content, sehingga tidak dijadikan landasan bagi pelaku pasar untuk melakukan investasi.

Beberapa penelitian lain tentang reaksi harga saham saat pengumuman dividen telah dilakukan. Namun, antara satu penelitian dengan penelitian lainnya menunjukkan hasil yang tidak konsisten. Gantyowati dan Sulistiyani (2008) menemukan hasil bahwa pengumuman dividen direaksi oleh pasar, yang ditandai dengan adanya Security Return Variability (SRV) dan Trading Volume Activity (TVA) signifikan sekitar tanggal pengumuman dividen. Akbar dan Baig (2010) juga menemukan hasil bahwa terdapat pengaruh positif dan signifikan dari pengumuman dividen pada harga saham di Pakistan. Begitu pula dengan penelitian Laabs dan Bacon (2013) yang menunjukkan hasil bahwa terjadi reaksi pasar positif dan signifikan saat pengumuman kenaikan dividen perusahaan. Hasil juga mendukung teori pasar efisien dalam bentuk setengah kuat pada perusahaan yang terdaftar di NYSE dan NASDAQ. Tran dan Mai (2015) juga menemukan bahwa pengumuman dividen memiliki dampak positif pada harga saham dan volume perdagangan di pasar saham Ho Chi Minh, Vietnam. Peneliti lain yang menemukan bahwa pengumuman dividen direaksi oleh pasar adalah Yulia dan Artini (2015). Mereka menemukan bahwa terdapat perbedaan abnormal return yang signifikan sebelum dan setelah pengumuman dividen di Bursa Efek Indonesia. Penelitian Na'im dan Herlambang (2015) juga menemukan bahwa terdapat reaksi pasar disekitar cum dividend. Hasil dari beberapa penelitian tersebut mengindikasikan bahwa pengumuman dividen memiliki kandungan informasi. 
Hasil yang berbeda ditemukan oleh Uddin dan Chowdhury (2005), yang menunjukkan bahwa investor tidak mendapatkan keuntungan dari pengumuman dividen, serta pembayaran dividen bukan merupakan sinyal informasi kepada investor pada Dhaka Stock Exchange. Asamoah dan Nkrumah (2010) juga menemukan bahwa pengumuman dividen tidak mempengaruhi perilaku harga pasar saham di Ghana Stock Exchange (GSE), dan pasar tidak efisien dalam bentuk setengah kuat. Begitu pula hasil penelitian Timmermans (2011) yang menemukan bahwa pasar bereaksi negatif terhadap pengumuman perubahan dividen, dan tidak terdapat abnormal return yang signifikan selama periode jendela. Hasil serupa juga ditemukan oleh Telceken dan Ocal (2015) bahwa terdapat hubungan negatif antara dividen per saham dan abnormal return, dimana terdapat reaksi pasar yang negatif saat dividen diumumkan.

Beberapa hasil penelitian sebelumnya mengenai pengaruh pengumuman dividen pada reaksi harga saham masih terdapat inkonsistensi, sehingga perlu diteliti kembali mengenai faktor yang dapat memoderasi pengaruh hubungan tersebut. Pada penelitian ini, digunakan variabel free cash flow sebagai variabel yang diprediksi mampu memoderasi pengaruh pengumuman dividen pada reaksi harga saham. Hal ini dikarenakan keputusan suatu perusahaan untuk membagikan dividen tunai kepada pemegang saham, tergantung pada posisi kas perusahaan tersebut. Posisi kas yang tersedia untuk pemegang saham dicerminkan oleh free cash flow yang dimiliki perusahaan. Brown (1996) menyatakan bahwa free cash flow sebagai aliran kas yang dihasilkan dari kegiatan operasional perusahaan, yang tersedia untuk dibagikan kembali kepada para pemegang saham tanpa 
Ni Wy. Lady Andini, Md. Gd. Wirakusuma, dan I D.G. Dharma Suputra. Reaksi Harga......

memengaruhi tingkat pertumbuhan perusahaan. Francis et al. (2000) dan Brigham et al. (1999) juga memberikan pengertian mengenai aliran kas bebas. Mereka menyatakan bahwa aliran kas bebas merupakan kas yang tersedia untuk dibagikan kepada investor, setelah terpenuhinya seluruh kebutuhan investasi yang digunakan untuk mempertahankan operasional perusahaan. Apabila perusahaan membayarkan dividen tunai, berarti uang kas harus tersedia dalam jumlah yang cukup banyak. Perolehan laba yang tinggi dalam suatu perusahaan, yang tidak diikuti dengan keadaan posisi kas yang baik, menyebabkan kemungkinan perusahaan tidak dapat membayar dividen.

Penelitian yang dilakukan oleh Holder et al. (1998) serta Mollah et al. (2002) memberikan saran agar perusahaan yang memiliki free cash flow tinggi, seharusnya mendistribusikan dividen lebih tinggi pula, untuk dapat meminimalisir risiko penyalahgunaan free cash flow oleh para manajer. Selain itu, Jensen (1986) menyatakan bahwa free cash flow sebaiknya didistribusikan sebagai dividen atau digunakan untuk melunasi utang, agar terhindar dari kemungkinan para manajer melakukan investasi yang dapat merugikan perusahaan. Pembagian dividen juga dapat mengurangi biaya keagenan, karena free cash flow yang tersedia untuk manajer juga berkurang (Mahadwartha dan Hartono, 2002). Oleh karena itu, ketika perusahaan mengumumkan pembagian dividen disertai dengan adanya free cash flow, maka diprediksi dapat meningkatkan harga saham perusahaan tersebut.

Berdasarkan hal yang telah dipaparkan di atas, maka dilakukanlah pengujian reaksi harga saham pada saat pengumuman dividen tunai dengan free cash flow sebagai pemoderasi di Bursa Efek Indonesia. Hal ini bertujuan untuk mendapatkan 
bukti empiris mengenai reaksi harga saham saat pengumuman dividen tunai, dan untuk mengetahui peran free cash flow dalam memoderasi pengaruh pengumuman dividen tunai pada reaksi harga saham di Bursa Efek Indonesia. Rumusan masalah penelitian terdiri dari: 1) Apakah pengumuman dividen tunai berpengaruh pada reaksi harga saham? dan 2) Apakah free cash flow mampu memoderasi pengaruh pengumuman dividen tunai pada reaksi harga saham?

Pengumuman tentang dividen diprediksi memiliki kandungan informasi apabila pasar bereaksi saat pengumuman tersebut diterima. Berdasarkan hipotesis efisiensi pasar, harga saham bereaksi terhadap informasi yang ada, termasuk di dalamnya mengenai informasi tentang pembagian dividen (Ang, 1997). Informasi pembagian dividen dipercaya dapat memengaruhi pergerakan harga saham di bursa, disebabkan oleh tindakan investor yang menginginkan keuntungan dari peristiwa tersebut. Sularso (2003) menemukan bahwa terdapat reaksi dari return saham terhadap pengumuman dividen dilihat dari jumlah dividen yang dibagikan. Pembayaran dividen yang meningkat sering ditafsirkan sebagai keyakinan manajemen terhadap prospek dan kinerja perusahaan yang semakin baik di masa mendatang.

Beberapa penelitian terdahulu menunjukkan reaksi pasar yang positif pada pengumuman dividen. Akbar dan Baig (2010) menemukan hasil bahwa pengumuman dividen berpengaruh positif dan signifikan pada harga saham di Pakistan. Begitu pula dengan penelitian Laabs dan Bacon (2013) yang menunjukkan hasil bahwa terjadi reaksi pasar positif dan signifikan sebelum pengumuman kenaikan dividen perusahaan. Hasil juga mendukung teori pasar 
Ni Wy. Lady Andini, Md. Gd. Wirakusuma, dan I D.G. Dharma Suputra. Reaksi Harga......

efisien dalam bentuk setengah kuat pada perusahaan yang terdaftar di NYSE dan NASDAQ. Penelitian Yulia dan Artini (2015) menemukan bahwa terdapat perbedaan abnormal return yang signifikan sebelum dan setelah pengumuman dividen di Bursa Efek Indonesia. Penelitian Na'im dan Herlambang (2015) juga menemukan bahwa terdapat reaksi pasar disekitar cum dividend. Hal tersebut menunjukkan bahwa pengumuman dividen memiliki kandungan informasi. Selain itu, Tran dan Mai (2015) juga menemukan bahwa pengumuman dividen memiliki dampak positif pada harga saham dan volume perdagangan di pasar saham Ho Chi Minh, Vietnam.

$\mathrm{H}_{1}$ : Pengumuman dividen tunai berpengaruh positif pada reaksi harga saham

Meski beberapa penelitian sebelumnya menunjukkan hasil yang positif, namun terdapat pula beberapa penelitian yang menunjukkan arah yang sebaliknya, bahkan menyatakan bahwa pengumuman dividen tidak memiliki pengaruh pada harga saham. Penelitian yang dilakukan Amah dan Nuraina (2012), menunjukkan hasil bahwa pengumuman dividen tidak memiliki information content, sehingga tidak dijadikan landasan bagi pelaku pasar untuk melakukan investasi. Investor tidak mendapatkan keuntungan dari pengumuman dividen, serta pembayaran dividen bukan merupakan sinyal informasi kepada investor pada Dhaka Stock Exchange (Uddin dan Chowdhury, 2005). Timmermans (2011) juga menemukan bahwa reaksi pasar negatif terhadap pengumuman perubahan dividen, dan tidak terdapat abnormal return yang signifikan selama periode jendela. Hasil serupa juga ditemukan oleh Telceken dan Ocal (2015) bahwa terdapat hubungan negatif antara 
dividen per saham dan abnormal return, dimana pasar bereaksi negatif pada pengumuman dividen.

Dividen yang dibagikan kepada pemegang saham, sangat bergantung pada kebijakan suatu perusahaan. Gitman (2003) menyatakan faktor-faktor yang memengaruhi kebijakan dividen suatu perusahaan diantaranya: debt covenant, likuiditas, posisi kas, prospek pertumbuhan perusahaan, dan kuasa kendali para pemegang saham mayoritas saham perusahaan. Pembayaran dividen, khususnya dividen tunai kepada para pemegang saham bergantung pada posisi kas yang tersedia. Hal ini dibuktikan oleh penelitian Sutrisno (2001) yang menemukan bahwa hanya faktor posisi kas (cash position) dan Debt to Equity Ratio yang berpengaruh signifikan di antara beberapa faktor lain yang mempengaruhi Dividend Payout Ratio.

Free Cash Flow atau aliran kas bebas menggambarkan tingkat fleksibilitas keuangan perusahaan. Jensen (1986) mendefinisikan aliran kas bebas sebagai kas yang tersisa setelah seluruh proyek yang menghasilkan net present value positif dilakukan. Perusahaan dengan free cash flow berlebih akan memiliki kinerja yang lebih baik dibandingkan perusahaan lainnya. Hal ini karena perusahaan dapat menggunakan free cash flow untuk memperoleh keuntungan atas berbagai kesempatan yang mungkin tidak dapat diperoleh perusahaan lain. Perusahaan yang memiliki free cash flow tinggi diduga lebih survive dalam situasi yang buruk. Sedangkan, apabila terdapat free cash flow yang negatif, berarti sumber dana internal perusahaan tidak mencukupi untuk memenuhi kebutuhan investasi, sehingga memerlukan tambahan dana eksternal baik dalam bentuk utang maupun 
Ni Wy. Lady Andini, Md. Gd. Wirakusuma, dan I D.G. Dharma Suputra. Reaksi Harga......

penerbitan saham baru. Semakin kuat posisi kas suatu perusahaan, akan memengaruhi besarnya kemampuan perusahaan tersebut dalam membayar dividen, sehingga akan menyebabkan pergerakan harga saham.

$\mathrm{H}_{2}$ : Free cash flow memperkuat pengaruh pengumuman dividen tunai pada harga saham

\section{METODE PENELITIAN}

Penelitian ini dilakukan pada perusahaan yang terdaftar di Bursa Efek Indonesia (BEI) tahun 2013-2015. Data yang digunakan dalam penelitian ini merupakan data sekunder. Pada penelitian ini, data sekunder berasal dari laporan keuangan perusahaan selama tiga periode yang dipublikasikan di Bursa Efek Indonesia dengan mengakses website www.idx.co.id. Selain itu, data sekunder mengenai informasi sehubungan dengan harga saham harian perusahaan, diperoleh dari Yahoo Finance dengan mengakses website www.finance.yahoo.com. Populasi dalam penelitian ini adalah seluruh perusahaan yang terdaftar di Bursa Efek Indonesia selama periode tahun 2013-2015. Populasi tahun 2013 berjumlah 486 perusahaan, tahun 2014 berjumlah 509, dan tahun 2015 berjumlah 525 perusahaan. Bursa Efek Indonesia dipilih karena perusahaan-perusahaan yang terdaftar di BEI merupakan emiten yang mewakili perusahaan dengan kinerja yang baik di Indonesia. Teknik pengambilan sampel yang digunakan dalam penelitian ini adalah metode purposive sampling. Jumlah sampel yang diteliti dalam penelitian ini adalah sebanyak 32 sampel tahun 2013, 34 sampel tahun 2014, dan 25 sampel tahun 2015, dengan 91 data amatan. Kriteria yang digunakan dalam pemilihan sampel: 1) Perusahaan mengumumkan dividen tunai meningkat tahun 2013 hingga 2015; 2) 
Perusahaan tidak melakukan corporate issue selain pengumuman dividen tunai seperti: right issue, stock split, merger atau akuisisi, yang dapat memengaruhi abnormal return selama periode pengamatan; 3) Saham yang dimiliki emiten aktif diperdagangkan selama periode pengamatan, sehingga dapat melihat perubahan harga sahamnya; 4) Data tersedia secara lengkap sehubungan dengan pengumuman dividen tunai.

Variabel penelitian terdiri dari variabel dependen, variabel independen, dan variabel moderasi. Variabel dependen dalam penelitian ini adalah reaksi harga saham, yang diproksikan dengan abnormal return. Abnormal return atau excess return merupakan kelebihan dari return yang sesungguhnya terjadi terhadap return normal, yang dihitung dengan rumus (Hartono, 2014:648):

$$
\mathrm{RTN}_{\mathrm{i}, \mathrm{t}}=\mathrm{R}_{\mathrm{i}, \mathrm{t}}-\mathrm{E}\left[\mathrm{R}_{\mathrm{i}, \mathrm{t}}\right]
$$

Keterangan:

$\mathrm{RTN}_{\mathrm{i}, \mathrm{t}}=$ return tak normal (abnormal return) sekuritas ke-i pada periode peistiwa ke-t.

$\mathrm{R}_{\mathrm{i}, \mathrm{t}} \quad=$ return realisasian yang terjadi untuk sekuritas ke-i pada periode peistiwa ke-t.

$\mathrm{E}\left[\mathrm{R}_{\mathrm{i}, \mathrm{t}}\right]=$ return ekspektasian sekuritas ke-i pada periode peistiwa ke-t.

Return realisasian dicari dengan menggunakan rumus sebagai berikut

$$
R_{i, t} \frac{P_{i, t}-P_{i, t-1}}{P_{i, t-1}}
$$

$\mathrm{R}_{\mathrm{it}}=$ return saham $\mathrm{i}$ pada hari $\mathrm{t}$

$\mathrm{P}_{\mathrm{i}, \mathrm{t}}=$ harga saham i pada hari $\mathrm{t}$

$\mathrm{P}_{\mathrm{i}, \mathrm{t}-1}=$ harga saham $\mathrm{i}$ pada hari $\mathrm{t}-1$

Sedangkan return ekspektasian menggunakan return yang harus diestimasi, yang pada penelitian ini menggunakan market-adjusted model. Market-adjusted 
Ni Wy. Lady Andini, Md. Gd. Wirakusuma, dan I D.G. Dharma Suputra. Reaksi Harga......

model menganggap bahwa penduga yang terbaik untuk mengestimasi return suatu sekuritas adalah return indeks pasar pada saat tersebut (Hartono, 2014:659).

Variabel independen dalam penelitian ini adalah pengumuman dividen. Pengumuman dividen diproksikan dengan dividend per share. Dividend Per Share (DPS) merupakan bagian keuntungan yang diberikan kepada para pemegang saham yang jumlahnya sebanding dengan jumlah saham yang dimiliki. Dividend Per Share (DPS) dihitung menggunakan rumus:

$$
\text { DPS }=\frac{\text { Total dividen yang dibagikan }}{\text { Jumlah Lembar saham yang beredar }}
$$

Variabel moderasi yaitu free cash flow dihitung menggunakan rumus (yang dinyatakan dalam satuan rupiah) (Rahmawati, 2012), yaitu:

$$
\text { FCFit }=\text { AKOit }- \text { PMit }- \text { NWCit }
$$

Keterangan:

FCFit : Free cash flow

AKOit : Arus kas operasi perusahaan i pada tahun $\mathrm{t}$

PMit : Pengeluaran modal perusahaan i pada tahun $t$

NWCit : Modal kerja bersih perusahaan i pada tahun $\mathrm{t}$

Teknik analisis data yang digunakan dalam penelitian ini adalah analisis moderasi atau Moderated Regression Analysis (MRA). Model regresi pada penelitian ini menggunakan persamaan sebagai berikut.

$$
Y=\beta_{0}+\beta_{1} X_{1}+\beta_{2} X_{2}+\beta_{3} X_{1} X_{2}+\varepsilon
$$

Keterangan:

Y $=$ Variabel dependen reaksi harga saham

$\beta_{0} \quad=$ Konstanta

$\mathrm{X}_{1} \quad=$ Variabel independen pengumuman dividen tunai

$\mathrm{X}_{2} \quad=$ Variabel moderasi free cash flow

$\beta_{1}, \beta_{2}, \beta_{3}=$ Koefisien regresi

$\mathrm{X}_{1} \mathrm{X}_{2}=$ Interaksi antara variabel independen pengumuman dividen tunai dengan variabel moderasi free cash flow 


\section{$\varepsilon \quad=$ Standard error}

Selain menggunakan tingkat signifikansi koefisien regresi variabel interaksi dalam penentuan variabel moderasi, dapat juga menggunakan pengelompokkan variabel moderator yang diajukan oleh Sharma et al. (1981) dalam Ghozali (2012:224) untuk mengidentifikasi dan menganalisis variabel moderasi secara lebih detail. Pengelompokkan variabel moderator tersebut disajikan pada Tabel 1.

Tabel 1.

Jenis-Jenis Variabel Moderator

\begin{tabular}{|c|c|c|}
\hline & $\begin{array}{c}\text { Berhubungan dengan kriterion } \\
\text { dan/atau prediktor }\end{array}$ & $\begin{array}{l}\text { Tidak berhubungan dengan } \\
\text { kriterion dan/atau prediktor }\end{array}$ \\
\hline $\begin{array}{c}\text { Tidak berinteraksi dengan } \\
\text { prediktor }\end{array}$ & $\begin{array}{c}1 \\
\text { Intervening, Exogen, Antesedent, } \\
\text { Prediktor }\end{array}$ & $\begin{array}{c}2 \\
\text { Moderator } \\
\text { (Homologizer) }\end{array}$ \\
\hline $\begin{array}{c}\text { Berinteraksi dengan } \\
\text { prediktor }\end{array}$ & $\begin{array}{c}3 \\
\text { Moderator } \\
\text { (Quasi Moderator) }\end{array}$ & $\begin{array}{c}4 \\
\text { Moderator } \\
\text { (Pure Moderator) }\end{array}$ \\
\hline
\end{tabular}
Sumber: Ghozali (2012:224)

Jika variabel moderator $\left(\mathrm{X}_{2}\right)$ berhubungan dengan kriterion $(\mathrm{Y})$ dan/atau prediktor $\left(\mathrm{X}_{1}\right)$, tetapi variabel moderator $\left(\mathrm{X}_{2}\right)$ tidak berinteraksi dengan prediktor $\left(\mathrm{X}_{1}\right)$ seperti tampak pada kuadran 1 , maka variabel $\mathrm{X}_{2}$ bukanlah moderator, tetapi merupakan variabel intervening, exogen, anteseden atau prediktor (independen). Secara konseptual, variabel pada kuadran 2 memengaruhi kekuatan hubungan, tetapi tidak berinteraksi dengan variabel prediktor $\left(\mathrm{X}_{1}\right)$ dan tidak berhubungan dengan signifikan, baik dengan prediktor $\left(\mathrm{X}_{1}\right)$ maupun dengan variabel kriterion (Y). Jenis moderator seperti ini disebut dengan variabel homologizer. Pada kuadran 3, variabel moderator $\left(\mathrm{X}_{2}\right)$ berhubungan dengan variabel kriterion $(\mathrm{Y})$ dan/atau variabel prediktor $\left(\mathrm{X}_{1}\right)$ serta berinteraksi dengan variabel prediktor $\left(\mathrm{X}_{1}\right)$. Jenis moderator pada kuadran 3 disebut quasi moderator (moderator semu). Pada kuadran 4 , variabel moderator $\left(\mathrm{X}_{2}\right)$ tidak berhubungan dengan variabel kriterion 
Ni Wy. Lady Andini, Md. Gd. Wirakusuma, dan I D.G. Dharma Suputra. Reaksi Harga......

(Y) dan prediktor $\left(\mathrm{X}_{1}\right)$, tetapi berinteraksi dengan variabel prediktor $\left(\mathrm{X}_{1}\right)$. Jenis moderator pada kuadran 4 ini disebut pure moderator (moderator asli).

Pada penelitian ini, peran variabel free cash flow berpotensi sebagai variabel intervening, exogen, anteseden atau prediktor (independen) dalam model hubungan yang dibentuk, apabila $\beta_{2}$ signifikan, sedangkan $\beta_{3}$ tidak signifikan. Apabila koefisien regresi $\beta_{2}$ dan $\beta_{3}$ tidak signifikan, maka variabel free cash flow disebut sebagai homologizer moderator, yang berarti variabel free cash flow potensial menjadi variabel moderasi. Free cash flow merupakan quasi moderator yang memoderasi hubungan antara pengumuman dividen tunai dengan reaksi harga saham, dan sekaligus menjadi variabel independen, apabila koefisien regresi $\beta_{2}$ dan $\beta_{3}$ signifikan. Apabila koefisien regresi $\beta_{2}$ tidak signifikan, sedangkan $\beta_{3}$ signifikan, maka free cash flow merupakan variabel pure moderator.

Penelitian ini juga menggunakan metode studi peristiwa (event study) untuk mengamati reaksi harga saham terhadap suatu pengumuman, dalam hal ini pengumuman dividen tunai di sekitar cum date. Studi peristiwa (event study) merupakan studi yang mempelajari reaksi pasar pada suatu peristiwa yang informasinya dipublikasikan sebagai suatu pengumuman. Studi peristiwa dapat digunakan untuk menguji kandungan informasi dari suatu pengumuman dan dapat juga digunakan untuk menguji efisiensi pasar bentuk setengah kuat (Hartono, 2014:623). Periode jendela yang digunakan pada penelitian ini adalah 7 hari pengamatan termasuk hari $\mathrm{H}$ pengumuman, tiga hari sebelum dan setelah pengumuman. Penggunaan periode jendela selama 7 hari dilakukan untuk menghindari adanya confounding effect. 
Metode yang digunakan dalam penelitian ini untuk mengetahui apakah terdapat kandungan informasi dari adanya pengumuman dividen tunai adalah uji beda. Pengumuman dividen tunai dikatakan mengandung informasi apabila terdapat perbedaan abnormal return sebelum dan sesudah pengumuman tersebut dilakukan. Sebelum melakukan analisis uji beda, maka dilakukan terlebih dahulu pengujian normalitas. Apabila data berdistribusi normal, langkah selanjutnya adalah dengan melakukan pengujian parametrik menggunakan uji beda t-test sampel berhubungan. Apabila data tidak berdistribusi normal, maka dilakukan pengujian non-parametrik yaitu dengan Uji Wilcoxon.

\section{HASIL DAN PEMBAHASAN}

Populasi penelitian ini terdiri atas seluruh perusahaan yang terdaftar di BEI periode 2013 hingga 2015. Jumlah populasi penelitian tahun 2013 sebanyak 486 perusahaan, tahun 2014 sebanyak 509 perusahaan, dan tahun 2015 sebanyak 525 perusahaan. Berdasarkan populasi ini, dilakukanlah pemilihan sampel menggunakan metode purposive sampling dan diperoleh sampel sejumlah 32 perusahaan untuk tahun 2013, 34 perusahaan untuk tahun 2014, dan 25 perusahaan untuk tahun 2015. Jumlah data amatan selama tiga tahun sebanyak 91 amatan. Rincian jumlah data amatan penelitian disajikan pada Tabel 2.

Tabel 2.

Rincian Jumlah Data Amatan Penelitian

\begin{tabular}{lccc}
\hline \multicolumn{1}{c}{ Keterangan } & $\mathbf{2 0 1 3}$ & $\mathbf{2 0 1 4}$ & $\mathbf{2 0 1 5}$ \\
\hline Populasi penelitian & 486 & 509 & 525 \\
Populasi yang tidak sesuai dengan kriteria purposive & $(454)$ & $(475)$ & $(500)$ \\
Sampel & $\mathbf{3 2}$ & $\mathbf{3 4}$ & $\mathbf{2 5}$
\end{tabular}


Ni Wy. Lady Andini, Md. Gd. Wirakusuma, dan I D.G. Dharma Suputra. Reaksi Harga......

Total pengamatan $(32+34+25)$

Sumber: Data diolah peneliti, 2017

91

Analisis statistik deskriptif dilakukan untuk memberikan gambaran atau deskripsi mengenai setiap variabel yang menunjukkan nilai rata-rata (mean), standar deviasi, nilai maksimum, serta nilai minimum. Rentangan antara nilai minimum dengan nilai maksimum dikatakan tidak terlalu jauh atau relatif pendek apabila nilai standar deviasi tidak dua kali lebih besar dari nilai rata-ratanya. Rentangan nilai minimum dan nilai maksimum variabel pengumuman dividen tunai dan free cash flow terlalu jauh atau relatif panjang. Sedangkan rentangan nilai minimum dan nilai maksimum variabel reaksi harga saham tidak terlalu jauh atau relatif pendek. Rangkuman hasil analisis statistik deskriptif penelitian disajikan pada Tabel 3.

Tabel 3.

Hasil Analisis Statistik Deskriptif

\begin{tabular}{lccccc}
\hline \multicolumn{1}{c}{ Variabel } & N & Minimum & Maksimum & Mean & $\begin{array}{c}\text { Standar } \\
\text { Deviasi }\end{array}$ \\
\hline Pengumuman Dividen & 91 & 1,51 & 2700,00 & 178,9857 & 357,89054 \\
Tunai $\left(\mathrm{X}_{1}\right)$ & & $\left.-90,55^{*}\right)$ & $46,88^{*)}$ & $\left.-3,64^{*}\right)$ & $\left.14,621^{*}\right)$ \\
Free Cash Flow $\left(\mathrm{X}_{2}\right)$ & 91 & $-0,07$ & 0,94 & 0,158 & 0,10332 \\
Reaksi Harga Saham (Y) & 91 & & & \\
${ }^{*}$ dalam triliun rupiah & & & & & \\
Sumber: Data diolah peneliti, 2017 & &
\end{tabular}

Sebelum melakukan analisis regresi moderasi, maka dilakukan uji asumsi klasik untuk memastikan agar model penelitian tidak melanggar asumsi-asumsi metode kuadrat terkecil, yaitu BLUE (Best, Linear, Unbias Estimator). Syaratsyarat asumsi klasik yang harus dipenuhi adalah data tersebut harus berdistribusi normal, tidak mengandung gejala multikolinearitas, autokorelasi dan heterokedastisitas. Uji normalitas bertujuan untuk menguji apakah dalam model regresi, variabel penganggu atau residual berdistribusi normal. Alat uji yang digunakan adalah 
dengan Kolmogorov-Smirnov (K-S), dimana kriteria ujinya adalah dengan membandingkan tingkat signifikansi dengan sig. alpha 0,05. Apabila nilai signifikansi Kolmogorov-Smirnov > 0,05, maka asumsi normalitas terpenuhi. Hasil uji normalitas pada penelitian ini dapat dilihat pada Tabel 4.

Tabel 4.

Hasil Uji Normalitas

\begin{tabular}{cc}
\hline $\mathbf{N}$ & Asymp. Sig. (2-tailed) \\
\hline 91 & 0,227 \\
\hline
\end{tabular}

Sumber: Data diolah peneliti, 2017

Hasil pengujian pada Tabel 4, diperoleh nilai signifikansi Kolmogorov-Smirnov (KS) sebesar 0,227. Nilai tersebut lebih besar dari 0,05 sehingga dapat disimpulkan bahwa asumsi normalitas pada model penelitian telah terpenuhi.

Uji multikolinearitas bertujuan untuk menguji apakah ditemukan korelasi antar variabel bebas (independen). Pendeteksian ada atau tidaknya korelasi antar sesama variabel bebas, dapat dilihat dari nilai tolerance dan nilai Variance Inflation Factor (VIF). Nilai cutoff bagi angka tolerance adalah sebesar 0,10 atau sama dengan nilai VIF diatas 10. Hasil uji multikolinearitas disajikan pada Tabel 5.

Tabel 5. Hasil Uji Multikolinearitas

\begin{tabular}{lcc}
\hline \multicolumn{1}{c}{ Variabel Bebas } & Tolerance & VIF \\
\hline Pengumuman Dividen Tunai $\left(\mathrm{X}_{1}\right)$ & 0,317 & 3,150 \\
Free Cash Flow $\left(\mathrm{X}_{2}\right)$ & 0,149 & 6,733 \\
Interaksi $\mathrm{X}_{1} * \mathrm{X}_{2}$ & 0,107 & 9,383 \\
\hline
\end{tabular}
Sumber: Data diolah peneliti, 2017

Berdasarkan hasil pengujian pada Tabel 5, diperoleh hasil bahwa seluruh variabel independen pada model penelitian memiliki nilai VIF kurang dari 10 dan nilai koefisien tolerance diatas 0,1 . Hal ini berarti bahwa tidak terdapat gejala multikolinearitas pada model regresi yang dibuat. 
Ni Wy. Lady Andini, Md. Gd. Wirakusuma, dan I D.G. Dharma Suputra. Reaksi Harga......

Uji Autokorelasi bertujuan menguji apakah dalam suatu model regresi linier ada korelasi antara kesalahan penganggu pada periode $t$ dengan kesalahan pada periode $\mathrm{t}-1$ (sebelumnya). Persyaratan yang harus dipenuhi agar model penelitian ini bebas dari gejala autokorelasi adalah nilai DW terletak diantara 1,7040 - 2,296 $\left(\mathrm{d}_{\mathrm{U}}<\mathrm{DW}<4-\mathrm{d}_{\mathrm{U}}\right)$. Hasil uji autokorelasi disajikan pada Tabel 6.

Tabel 6.

Hasil Uji Autokorelasi

\begin{tabular}{lcc}
\hline \multicolumn{1}{c}{ Variabel Bebas } & N & DW \\
\hline Pengumuman Dividen Tunai $\left(\mathrm{X}_{1}\right)$ & 91 & 1,964 \\
Free Cash Flow $\left(\mathrm{X}_{2}\right)$ & 91 & 1,964 \\
\hline
\end{tabular}

Sumber: Data diolah peneliti, 2017

Berdasarkan hasil pengujian pada Tabel 6, diperoleh hasil bahwa nilai DW adalah sebesar 1,964 lebih besar dari $\left(\mathrm{d}_{\mathrm{U}}\right)$ 1,7040 dan kurang dari 4 - 1,7040 (4 - $\left.\mathrm{d}_{\mathrm{U}}\right)$, maka dapat disimpulkan bahwa model regresi tidak mengandung gejala autokorelasi.

Uji heterokedastisitas bertujuan menguji apakah dalam model regresi terjadi ketidaksamaan variance dari residual satu pengamatan ke pengamatan yang lain. Kriteria tidak terjadi masalah heteroskedastisitas adalah apabila probabilitas signifikansinya di atas tingkat kepercayaan 5 persen atau apabila sig. $\mathrm{t}$ masingmasing variabel bebas lebih besar dari 0,05. Hasil uji heteroskedastisitas disajikan pada Tabel 7.

Tabel 7.

Hasil Uji Heteroskedastisitas

\begin{tabular}{ll}
\hline \multicolumn{1}{c}{ Variabel Bebas } & Sig. t \\
\hline Pengumuman Dividen Tunai $\left(\mathrm{X}_{1}\right)$ & 0,766 \\
Free Cash Flow $\left(\mathrm{X}_{2}\right)$ & 0,390 \\
Interaksi $\mathrm{X}_{1} * \mathrm{X}_{2}$ & 0,313 \\
\hline Sumber: Data diolah peneliti, 2017 &
\end{tabular}

Berdasarkan hasil pengujian pada Tabel 7, diperoleh hasil bahwa nilai signifikansi masing-masing variabel bebas memiliki nilai lebih besar dari 0,05. Hal ini 
menunjukkan bahwa model penelitian tidak memiliki masalah heteroskedastisitas, sehingga layak untuk digunakan.

Berdasarkan hasil pengujian asumsi klasik yang telah dilakukan dengan aplikasi SPSS versi 17.00, maka dapat disimpulkan bahwa data penelitian ini terdistribusi normal, bebas dari gejala multikolinearitas, autokorelasi, serta heteroskedastisitas. Sehingga data penelitian ini dapat dilanjutkan untuk diolah dengan teknik analisis moderasi atau Moderated Regression Analysis (MRA). Analisis moderasi atau Moderated Regression Analysis (MRA) digunakan untuk menguji hipotesis satu dan dua. Hasil pengujian MRA sesuai dengan output SPSS disajikan pada Tabel 8 .

Tabel 8.

Hasil Analisis Moderated Regression Analysis (MRA)

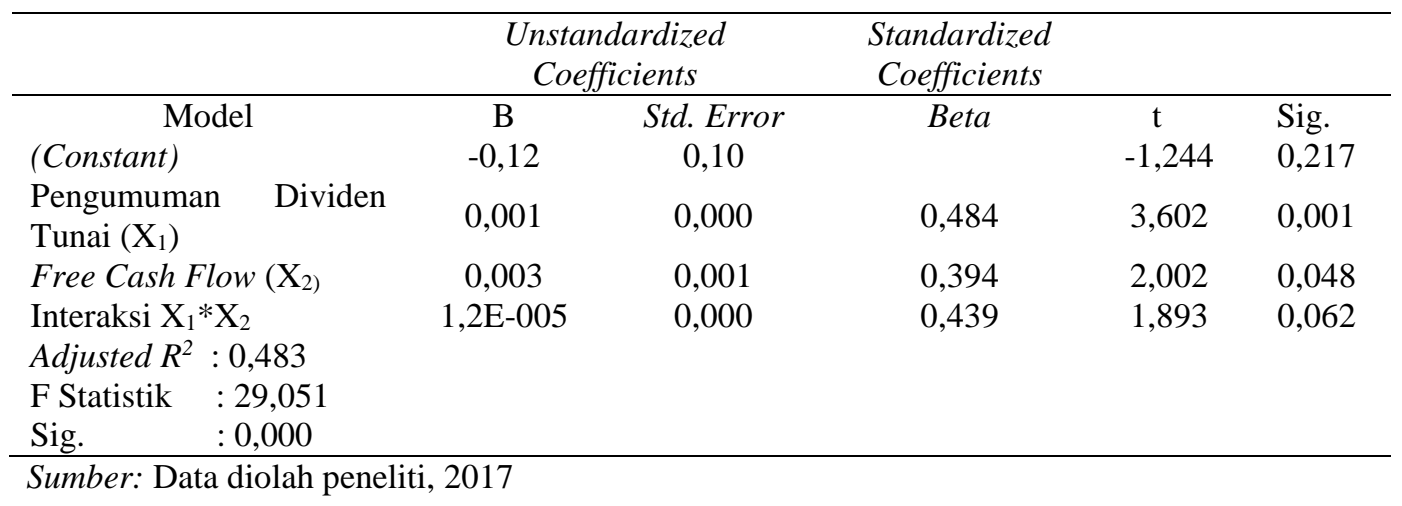

Berdasarkan hasil pengujian pada Tabel 8, maka persamaan regresi yang diperoleh adalah sebagai berikut.

$$
Y^{\prime}=-0,12+0,001 X_{1}+0,003 X_{2}+0,000012 X_{1} X_{2}+\varepsilon
$$

Keterangan:

$\mathrm{Y}^{\prime} \quad=$ Variabel dependen reaksi harga saham

$\beta_{0} \quad=$ Konstanta

$\mathrm{X}_{1} \quad=$ Variabel independen pengumuman dividen tunai

$\mathrm{X}_{2} \quad=$ Variabel moderasi free cash flow

$\beta_{1}, \beta_{2}, \beta_{3}=$ Koefesien regresi 
Ni Wy. Lady Andini, Md. Gd. Wirakusuma, dan I D.G. Dharma Suputra. Reaksi Harga......

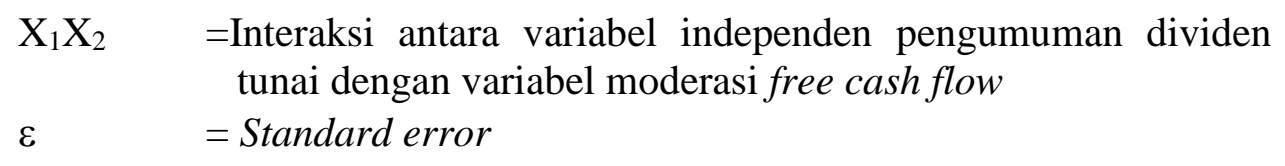

Berdasarkan Tabel 8, nilai Adjusted $R^{2}$ sebesar 0,483 atau (48,3\%). Hal ini menunjukkan bahwa sebesar 48,3\% variasi reaksi harga saham dapat dijelaskan oleh pengumuman dividen tunai, free cash flow, dan variabel interaksi $\mathrm{X}_{1} * \mathrm{X}_{2}$. Sedangkan sisanya sebesar $51,7 \%$ dipengaruhi atau dijelaskan oleh variabel lain yang tidak dimasukkan dalam model penelitian ini. Dilihat dari F statistik yang bernilai 29,051 (probabilitas signifikansi 0,000 <0,05), maka model penelitian ini layak digunakan untuk melakukan pembuktian atas hipotesis yang dibentuk atau dengan kata lain, model fit.

Pengumuman dividen tunai $\left(\mathrm{X}_{1}\right)$ memiliki koefisien regresi positif sebesar 0,001 dengan tingkat signifikansi sebesar 0,001 (lebih kecil dari $\alpha=0,05$ ). Hal ini berarti hipotesis satu diterima, yaitu pengumuman dividen tunai berpengaruh positif pada reaksi harga saham. Hasil penelitian ini sejalan dengan hasil penelitian yang dilakukan oleh Akbar dan Baig (2010), Laabs dan Bacon (2013), serta Tran dan Mai (2015). Selain itu, penelitian ini mendukung teori dividend signalling yang dicetuskan oleh Bhattacharya (1979). Teori dividend signalling menyatakan bahwa pengumuman perubahan dividen tunai mengandung informasi yang menyebabkan timbulnya reaksi pada harga saham. Teori ini menjelaskan bahwa informasi tentang dividen tunai yang dibayarkan dianggap oleh investor sebagai sinyal mengenai prospek perusahaan di masa yang akan datang. Investor menangkap sinyal positif saat perusahaan membagikan dividen, yang mengindikasikan perusahaan mempunyai prospek yang baik, sehingga harga saham mengalami peningkatan. 
Diterimanya hipotesis satu, diperkuat juga oleh hasil dari uji beda yang dilakukan. Uji beda pada Tabel 9 menunjukkan nilai Z-hitung sebesar -3,982 dengan nilai probabilitas sebesar 0,000 lebih kecil dari nilai alpha 0,05. Hal ini berarti terdapat perbedaan abnormal return yang signifikan antara sebelum dan sesudah pengumuman dividen dilakukan. Hasil ini sejalan dengan penelitian yang dilakukan Yulia dan Artini (2015) yang menemukan bahwa terdapat perbedaan abnormal return signifikan sebelum dan setelah pengumuman dividen di Bursa Efek Indonesia. Penelitian Na'im dan Herlambang (2015) juga menemukan bahwa terdapat reaksi pasar disekitar cum dividend. Hal ini berarti pengumuman pembagian dividen meningkat memiliki kandungan informasi, yang mengakibatkan pasar bereaksi. Kandungan informasi pengumuman dividen tunai terjadi secara cepat dan tidak berkepanjangan. Pasar hanya memerlukan waktu selama 2 hari $(\mathrm{H}+1$ dan $\mathrm{H}+2)$ setelah tanggal pengumuman untuk menuju ke keadaan ekuilibrium yang baru. Keadaan tersebut ditunjukkan oleh pergerakan kurva yang mulai naik kembali di $\mathrm{H}+3$ pada Gambar 1. Kecepatan reaksi dan tidak berkepanjangan, menunjukkan bahwa pasar telah efisien dalam bentuk setengah kuat secara informasi.

Tabel 9.

\section{Hasil Uji Beda}

\begin{tabular}{lc}
\hline & Sesudah - Sebelum \\
\hline $\mathrm{Z}$ & $-3,982^{\mathrm{a}}$ \\
\hline Asymp. Sig. (2-tailed) & 0,000 \\
\hline Sumber: Data diolah peneliti, 2017 &
\end{tabular}


Ni Wy. Lady Andini, Md. Gd. Wirakusuma, dan I D.G. Dharma Suputra. Reaksi Harga.......

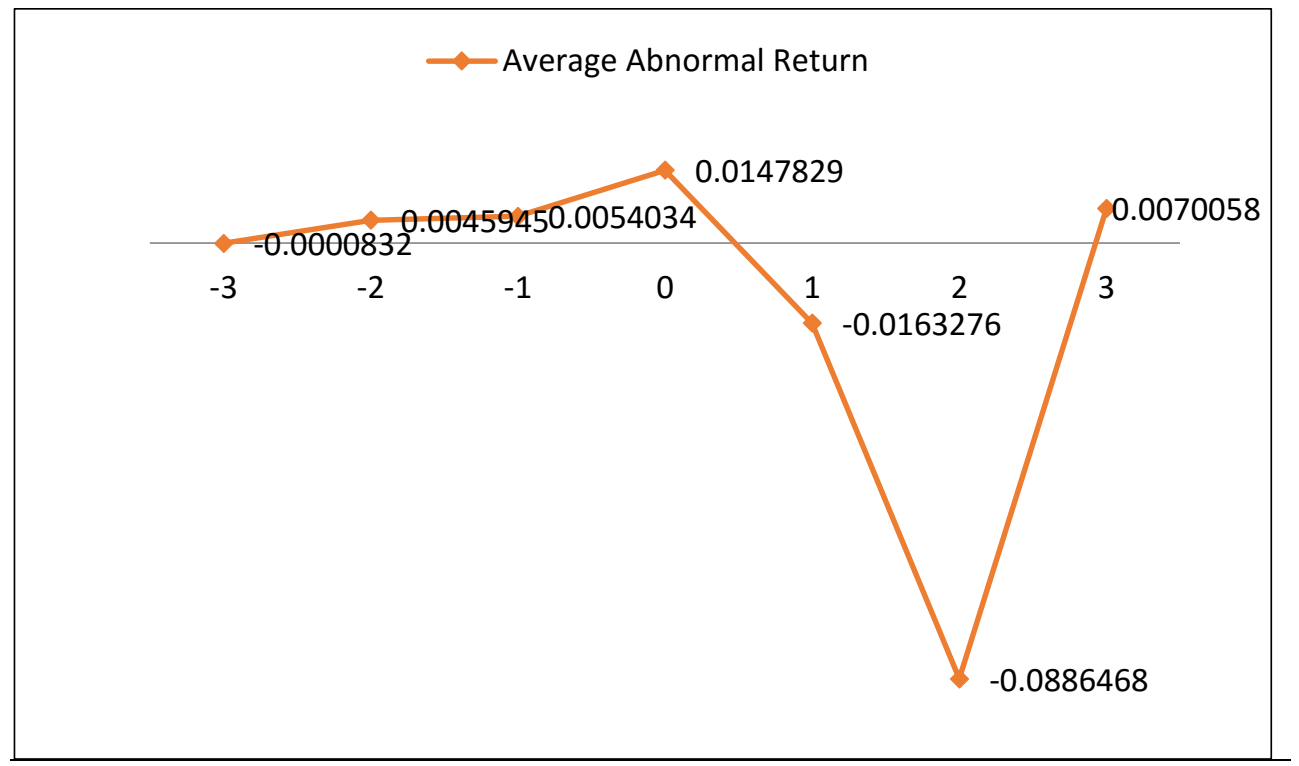

Sumber: Data diolah peneliti, 2017

Gambar 1. Pergerakan Average Abnormal Return

Pengujian pada hipotesis dua dilakukan untuk membuktikan kemampuan free cash flow dalam memperkuat pengaruh pengumuman dividen tunai pada reaksi harga saham. Hasil analisis MRA pada Tabel 8 menunjukkan interaksi variabel pengumuman dividen tunai dan free cash flow $\left(\mathrm{X}_{1} * \mathrm{X}_{2}\right)$ memiliki koefisien regresi positif sebesar 0,000012, namun tingkat signifikansinya lebih besar dari $\alpha=0,05$, yaitu sebesar 0,062. Hal ini menandakan bahwa hipotesis dua ditolak, yang berarti free cash flow tidak terbukti sebagai variabel pemoderasi yang memperkuat pengaruh pengumuman dividen tunai pada reaksi harga saham. Berdasarkan jenis moderator, variabel free cash flow pada penelitian ini berpotensi sebagai variabel intervening, exogen, anteseden atau prediktor (independen).

Free cash flow tidak terbukti memoderasi pengaruh pengumuman dividen tunai pada reaksi harga saham. Hal ini dikarenakan besarnya dividen yang dibagikan sudah ditentukan saat Rapat Umum Pemegang Saham (RUPS). Sebelum membuat keputusan mengenai besarnya dividen yang dibagikan, tentunya pihak 
manajemen perusahaan sudah memperhitungkan terlebih dahulu free cash flow yang dimiliki, sehingga cukup untuk melakukan pembayaran dividen kepada investor. Oleh karena itu, ketika suatu perusahaan mengumumkan pembagian dividen tunai, investor tidak lagi melakukan perhitungan free cash flow, untuk membuat keputusan membeli atau menjual saham perusahaan tersebut. Investor hanya akan melihat besarnya dividen yang dibagikan sebagai suatu pertimbangan untuk menahan atau melepas sahamnya. Investor beranggapan bahwa besarnya dividen tunai yang dibagikan, telah menggambarkan kondisi free cash flow perusahaan. Alasan lain yang menyebabkan free cash flow tidak terbukti memoderasi pengaruh pengumuman dividen tunai pada reaksi harga saham, adalah kesulitan investor dalam mengidentifikasi free cash flow melalui laporan keuangan perusahaan. Perhitungan mengenai free cash flow tidak secara langsung tersaji di dalam laporan keuangan, sehingga investor harus melakukan perhitungan kembali untuk mengetahui besarnya free cash flow yang terdapat dalam perusahaan.

\section{SIMPULAN DAN SARAN}

Berdasarkan hasil analisis data dan pembahasan, penelitian ini memperoleh dua kesimpulan. Pertama, pengumuman dividen tunai berpengaruh positif pada reaksi harga saham. Hal ini berarti semakin tinggi jumlah dividen tunai yang diumumkan, maka reaksi harga saham akan semakin baik (positif). Investor melihat pengumuman dividen tunai sebagai suatu informasi baik atau good news, sehingga menyebabkan reaksi pasar yang positif melalui kenaikan harga saham. Selain itu, 
Ni Wy. Lady Andini, Md. Gd. Wirakusuma, dan I D.G. Dharma Suputra. Reaksi Harga......

kecepatan reaksi yang terjadi dan tidak berkepanjangan menunjukkan bahwa pasar modal Indonesia telah efisien dalam bentuk setengah kuat secara informasi.

Kedua, free cash flow tidak terbukti sebagai pemoderasi yang memperkuat pengaruh pengumuman dividen tunai pada reaksi harga saham. Variabel free cash flow pada penelitian ini terbukti berpotensi sebagai variabel intervening, exogen, anteseden atau prediktor (independen). Tinggi rendahnya free cash flow yang terdapat dalam perusahaan, tidak lagi digunakan sebagai suatu pertimbangan oleh investor dalam keputusan menahan atau melepas sahamnya saat terjadi pengumuman dividen tunai. Hal ini karena free cash flow telah diperhitungkan oleh pihak manajemen perusahaan sebelum membuat keputusan mengenai besarnya dividen yang dibagikan, yang diumumkan saat Rapat Umum Pemegang Saham (RUPS).

Beberapa saran dapat diberikan berdasarkan penelitian ini, yaitu: 1) Calon investor maupun investor sebaiknya memerhatikan besarnya dividen yang dibagikan sebagai salah satu keputusan untuk membeli atau menjual saham yang dimiliki. 2) Perusahaan disarankan menambahkan perhitungan dan penjelasan mengenai free cash flow di dalam laporan keuangan. Hal ini dapat memudahkan investor untuk mengetahui besarnya free cash flow yang dimiliki perusahaan, tanpa harus melakukan perhitungan kembali. 3) Penelitian selanjutnya disarankan menggunakan variabel kebijakan dividen (meningkat atau menurun) sebagai variabel independennya. Pada penelitian ini variabel independen yang digunakan adalah pengumuman dividen, yang besar pembagian dividennya sudah diumumkan saat Rapat Umum Pemegang Saham (RUPS). Hal ini menyebabkan investor tidak 
lagi memerhatikan free cash flow dalam keputusan investasi. Oleh karena itu, ketika variabel kebijakan dividen digunakan, mungkin akan dapat membuktikan peran free cash flow sebagai pemoderasi. Selain itu, berdasarkan jenis variabel moderator, free cash flow dalam penelitian ini berpotensi sebagai variabel intervening, exogen, anteseden atau prediktor (independen). Hal ini dapat diteliti kembali untuk memberikan bukti empiris mengenai peran free cash flow tersebut. Penelitian ini juga memiliki kelemahan yang disebabkan oleh keterbatasan data. Pada penelitian ini, dividen yang dibagikan tetap meningkat, reaksi harga saham juga positif, padahal perhitungan free cash flow sebagian besar bertanda negatif atau mengalami minus. Hal ini disebabkan oleh periode pengumuman dividen yang digunakan adalah setelah dilaksanakannya RUPS, sedangkan data perhitungan free cash flow diambil dari laporan keuangan tahunan yang dijadikan sebagai dasar pengambilan keputusan saat RUPS tersebut dilaksanakan. Sehingga disarankan agar menggunakan periode terjadinya RUPS untuk mendapatkan data yang lebih baik dalam merepresentasikan pengumuman dividen.

\section{REFERENSI}

Akbar, Muhammad dan Humayun Habib Baig. 2010. Reaction of Stock Prices to Dividend Announcements and Market Efficiency in Pakistan. The Lahore Journal of Economics. Vol. 15(1): 103-125.

Al-Yahyaee, K. H., Pham, T. M., dan Walter, T. S. 2011. The Information Content of Cash Dividend Announcements In A Unique Environment. Journal of Banking \& Finance. Vol. 35(3): 606-612.

Amah, Nik dan Nuraina Elva. 2012. Reaksi Pasar sebagai Dampak dari Publikasi Dividen Studi Empiris pada Perusahaan Manufaktur yang Terdaftar di Bursa Efek Indonesia Tahun 2004-2006. Prestasi. Vol. 10(2): 105-116. 
Ni Wy. Lady Andini, Md. Gd. Wirakusuma, dan I D.G. Dharma Suputra. Reaksi Harga......

Ang, Robbert. 1997. Buku Pintar Pasar Modal Indonesia. Edisi Pertama. Mediasoft Indonesia.

Asamoah, Gordon Newlove dan Kwame Nkrumah. 2010. The Impact of Dividend Announcement on Share Price Behaviour in Ghana. Journal of Business \& Economics Research. Vol. 4(8): 47-58.

Bhattacharya, S. 1979. Imperfect Information, Dividend Policy and the Bird in the Hand Fallacy. Bell Journal of Economics. Vol. 10 (1): 259-270.

Brigham, Eugene E., Louis C. Gapenski, dan Philip R. Daves. 1999. Intermediate Financial Management. 6th Edition. Orlando: The Dryden Press.

Brown, Gordon T. 1996. Free Cash Flow Appraisal... A Better Way?. The Appraisal Journal.

Bursa Efek Indonesia (BEI). 2016, (online), (http://www.idx.co.id) diakses 11 Oktober 2016.

Easton, A., dan Sinclair, A. 1989. The Impact of Unexpected Earnings and Dividends on Abnormal Returns to Equity. Accounting \& Finance. Vol. 29: 1-19.

Foster III, W., dan Vickrey, D. 1978. The Information Content of Dividend Announcements. The Accounting Review. Vol. 53: 360-370.

Francis, Jennifer, Perl Olsson dan Dennis R. Oswald. 2000. Comparing The Accuracy and Explainability of Dividend, Free Cash Flow, and Abnormal Earning Equity Estimates. Journal of Accounting Research. Vol. 38(1): 45-70.

Gantyowati, Evi dan Yayuk Sulistiyani. 2008. Reaksi Pasar terhadap Pengumuman Dividen pada Perusahaan yang Masuk Corporate Governance Perception Index. Jurnal Bisnis dan Akuntansi. Vol. 10(3): 161-171.

Ghozali, Imam. 2012. Aplikasi Analisis Multivariate dengan Program SPSS. Edisi 6. Semarang: Badan Penerbit Fakultas Ekonomi Universitas Diponegoro.

Gordon, Myron J. 1959. Dividend, Earning, and Stock Prices. The Review of Economics and Statistics. Vol. 41(2): 99-105.

Gordon, Myron J. 1962. The Savings Investment and Valuation of a Corporation. The Review of Economics and Statistics. Vol. 44: 37-51.

Hartono, Jogiyanto. 2014. Teori Portofolio dan Analisis Investasi. Yogyakarta: BPFE Yogyakarta. 
Holder, M., F. Langrehr, and J. Hexter. 1998. Dividend Policy Determinants: An Investigation of the Influences of Stakeholder Theory. Financial Management 27, pp.73- 82 .

Jensen, Michael C. 1986. Agency Costs of Free Cash Flow, Corporate Finance, and Takeovers. American Economic Review. Vol. 76(2): 323-329.

Laabs, Douglas S dan Bacon, Frank W. 2013. The Impact of Increased Dividend Announcements on Stock Price: A Test of Market Efficiency. ASBBS Annual Conference. Las Vegas.

Lee, B. 1995. The Response of Stock Prices to Permanent and Temporary Shocks to Dividends. Journal of Financial and Quantitative Analysis. Vol. 30: 1-22.

Lintner, John. 1962. Distribution of Income of Corporations Among Dividends, Retained Earnings, and Taxes. The American Economics Riview. May: Hal. 97-133.

Mahadwartha, Putu Anom dan Jogiyanto Hartono. 2002. Uji Teori Keagenan dalam Hubungan Interpendensi antara Kebijakan Hutang dengan Kebijakan Dividen. Simposium Nasional Akuntansi V. Semarang.

Mollah, A. S, K. Keasey, and H. Short. 2002. The Influence of Agency costs on Dividend Policy in An Emerging Market: Evidence from the Dhaka stock Exchange. Working Paper. Leeds University Business School.

Na'im, Mohammad Mulfi dan Leo Herlambang. 2015. Analisis Reaksi Pasar atas Pengumuman Cum Dividen (Studi pada Saham yang Terdaftar di Jakarta Islamic Index Tahun 2012-2013). JESTT. Vol. 2(1): 61-76

Nugroho, K. A. 2014. Analisis Reaksi Pasar terhadap Pengumuman. Laporan Penelitian. Surakarta: Universitas Sebelas Maret.

Sularso, R. A. 2003. Pengaruh Pengumuman Dividen terhadap Perubahan Harga Saham (Return) Sebelum dan Sesudah Ex-Dividend Date di Bursa Efek Jakarta (BEJ). Jurnal Akuntansi dan Keuangan Vol. 5(1).

Sutrisno. 2001. Analisis Faktor-faktor yang mempengaruhi Dividend Payout Ratio. TEMA. Vol 2(1), Maret 2001.

Telçeken, Eyüp Kadığlu, Niyazi dan Nurcan Öcal. 2015. Market Reaction to Dividend Announcement: Evidence from Turkish Stock Market. International Business Research. Vol. 8(9): 83-94.

Timmermans. 2011. "Dividend Announcements and Capital Market Efficiency" (thesis). Faculty of Economics and Business Administration: Tilburg University. 
Ni Wy. Lady Andini, Md. Gd. Wirakusuma, dan I D.G. Dharma Suputra. Reaksi Harga......

Tran, Quoc Trung dan Y Dat Mai. 2015. Stock Market Reaction to Dividend Announcements from a Special Institutional Environment of Vietnamese Stock Market. International Journal of Economics and Finance. Vol. 7(9): 50-58.

Uddin, Md. Hamid dan Golam Mohammed Chowdhury. 2005. Effect of Dividend Announcement on Shareholder's Value: Evidence From Dhaka Stock Exchange. Journal of Business Research. Vol. 7: 1-11.

Yahoo Finance. 2017, (online), (http://finance.yahoo.com/) diakses 18 Februari 2017.

Yulia, I Gusti Ayu Artisca dan Luh Gede Sri Artini. 2015. Dampak Pengumuman Dividen terhadap Abnormal Return pada Perusahaan LQ45 yang Terdaftar di Bursa Efek Indonesia. E-Jurnal Manajemen Unud ISSN : 2302-8912. Vol.4(12): 44494476. 